九州大学学術情報リポジトリ

Kyushu University Institutional Repository

The Parasitoids of Dryocosmus kuriphilus Yasumatsu (Hymenoptera: Cynipidae) in Japan and the Introduction of a Promising Natural Enemy from China (Hymenoptera : Chalcidoidea)

Murakami, Yozo

Division of Insect Natural Enemies, Institute of Biological Control, Faculty of Agriculture, Kyushu University

https://doi.org/10.5109/23728

出版情報 : 九州大学大学院農学研究院紀要. 25 (4), pp. 167-174, 1981-04. Kyushu University バージョン：

権利関係 : 


\title{
The Parasitoids of Dryocosmus kuriphilus Yasumatsu (Hymenoptera: Cynipidae) in Japan and the Introduction of a Promising Natural Enemy from China (Hymenoptera : Chalcidoidea) *
}

\author{
Yôzô Murakami \\ Division of Insect Natural Enemies, Institute of Biological Control, Faculty \\ of Agriculture, Kyushu University 46-13. Fukuoka 812
}

(Received December 19. 1980)

\begin{abstract}
Dryocosmus kuriphilus is one of the most serious pests of chestnut trees in Japan which entered from China about 1941. Among 15 species of native parasitoids, Torymus (Syntomaspis) beneficus is the most important natural enemy but it has not been recognized as an effective natural enemy capable of regulating the pest population under an acceptable economic injury level. Recently 10 species of the parasitoids were recorded from China. Among them a promising natural enemy, Torymus (Syntomaspis) sp. was imported into Japan and was released for propagation. The Chinese species is very closely related to the Japanese beneficus but distinguishable by the length of the ovipositor. The emergence period of the Chinese species is more synchronous with the host than is beneficus.
\end{abstract}

\section{INTRODUCTION}

Most cynipid gall wasps make galls usually on Quercus trees and in a few cases on rose trees. The chestnut gall wasp, Dryocosmus kuriphilus Yasumatsu is the only species of gall-making cynipid associated with chestnut trees (Cas. tanea spp.) in the world. It was first recognized in Okayama Prefecture, Japan about 1941 (Shiraga, 1951), and it spread rapidly throughout Japan, becoming one of the most serious pests of chestnut trees. Control by various insecticides and natural enemies has been attempted but neither approach has been effective. It was found, however, that there were several chestnut varieties resistant to the gall wasp, therefore, efforts have concentrated on breeding and propagating resistant varieties. Because of this effort and success, gall wasp then became less of a problem. More recently, however, the cynipid gall wasps have overcome any benefit gained by use of resistant varieties. Reduction of the effectiveness of the resistant varieties is probably due to the selection and development of a new, more tolerant biotype of the gall wasp. Thus the gall wasp has again become a serious pest of chestnut trees. Therefore, the biological control of the pest has become currently desirable for chestnut growers in Japan.

* Presented at the XVI International Congress of Entomology, Kyoto August 3-9, 1980. 


\section{NATIVE PARASITOIDS IN JAPAN}

The chestnut gall wasp has one generation a year. The adults emerge from galls in early summer and immediately oviposit thelytokously in leaf buds. Larvae hibernate in the buds at an early stage, and in early spring they continue to develop and induce gall formation.

Yasumatsu (1955) reported preliminarily on the native parasitoids of the chestnut gall wasp and he stated that among the many parasitoids which he found, 11 species were of importance. Recently, Yasumatsu and Kamijo (1979) published a taxonomic study on the parasitoids and they recorded 12 species of chalcidoids including 5 new species in Japan. Including two additional chalcidoids recorded by Yasumatsu (1955) and one braconid described by Watanabe (1957), fifteen species of native parasitoids have been recorded in Japan (Table 1). Probably these parasitoids were originally attacking native cynipids on Quercus spp. before the chestnut gall wasp arrived in Japan.

As Askew (1975) has stated, most of the parasitoids associated with oak galls are polyphagous, attacking not only gall-makers but also inquiline cynipids and chalcidoid parasitoids, although parasitoids which belong to the genera Syntomaspis, Olynx, Pediobius and Omocerus are monophagous or oligophagous. Among the 15 species of native parasitoids of the chestnut gall wasp in Ja-

Table 1. Native parasitoids of Dryocosmus kuriphilus in Japan.

\begin{tabular}{|c|c|c|c|c|c|}
\hline \multirow[b]{2}{*}{ Species } & \multicolumn{4}{|c|}{ Distribution } & \multirow[b]{2}{*}{ References } \\
\hline & $\begin{array}{l}\text { Hok- } \\
\text { kaido }\end{array}$ & $\begin{array}{l}\text { Hon- } \\
\text { shu }\end{array}$ & $\begin{array}{l}\text { Shi- } \\
\text { koku }\end{array}$ & Kyushu & \\
\hline $\begin{array}{c}\text { Torymus (Syntomaspis) benejcus } \\
\text { Yasumatsu et Kamijo }\end{array}$ & IS + & + & + & + & Yasumatsu \& Kamijo (1979) \\
\hline T. (Torymus) geranii (Walker) & + & + & + & + & Yasumatsu \& Kamijo (1979) \\
\hline $\begin{array}{l}\text { Megastigmus nipponicus } \\
\text { Yasumatsu et Kamiio }\end{array}$ & + & + & + & + & Yasumatsu \& Kamijo (1979) \\
\hline $\begin{array}{l}\text { M. maculipennis } \\
\text { Yasumatsu et Kamijo }\end{array}$ & & + & + & + & Yasumatsu \& Kamijo (1979) \\
\hline Ormyrus punctiger Westwood & + & + & + & + & Yasumatsu \& Kamijo (1979) \\
\hline $\begin{array}{l}\text { 0. flavitibialis } \\
\text { Yasumatsu et Kamijo }\end{array}$ & & + & & $\mathrm{t}$ & Yasumatsu \& Kamijo (1979) \\
\hline Amblymerus sp.11 & & + & & + & Yasumatsu (1955) \\
\hline Eurytoma brunniventris Ratzeburg & $g+$ & + & & + & Yasumatsu \& Kamijo (1979) \\
\hline E. setigera Mayr & + & + & & $\mathrm{t}$ & $\begin{array}{l}\text { Murakami }(1979) ; \text { Yasumatsu } \\
\& \text { Kamijo (1979) }\end{array}$ \\
\hline E. schaeferi Yasumatsu et Kamijo & $o+$ & + & & + & Yasumatsu \& Kamijo (1979) \\
\hline Sycophila variegata (Curtis) & + & + & & + & Yasumatsu \& Kamijo (1979) \\
\hline Eupelmus urozonus Dalman & + & + & + & + & Yasumatsu \& Kamijo (1979) \\
\hline Gen. sp. (Eupelmidae) ${ }^{2)}$ & & + & + & + & Yasumatsu (1955) \\
\hline Cynipencyrtus flavus Ishii & & + & + & + & $\begin{array}{l}\text { Tachikawa (1978) ; Yasuma- } \\
\text { tsu \& Kamijo (1979) }\end{array}$ \\
\hline Aspilota yasumatsui Watanabe & & + & & & Watanabe (1957) \\
\hline
\end{tabular}

1) Yasumatsu (1955) regarded this parasitoid as a new subspecies of A. amoenus and proposed a subspecies name "japonicus" tentatively, but it has not yet been validated. 2) Yasumatsu (1955) regarded this as a new species belonging to a new genus and proposed a scientific name "Peleumus ferrierei", but it has not yet been validated. 
pan, Torymus (Syntomaspis) benejcus Yasumatsu et Kamijo is the only oligophagous parasitoid, and it is the most dominant one.

I investigated the biology of $T$. (S.) benejcus at Mt. Aburayama in a suburb of Fukuoka City and have obtained several knowledges about it. In early spring adults emerge from withered galls on chestnut trees formed in the previous year, and females oviposit in newly formed galls (Fig. 1). The egg is deposited in the larval chamber of the gall attached to the chamber wall (Fig. 2). The host was stung and paralyzed by the female parasitoid at the time of oviposition. The first instar larva feeds on the soft plant tissue of the chamber wall, Two or more eggs are frequently laid in a gall chamber but only one larva can survive. The supernumeraries are eliminated in early stages. (Table 2). After the larva develops to the second instar, it feeds ectoparasitically on the mature larvae of the chestnut gall wasp. After a month, the parasitoid develops mature larva and enters into a long diapause until autumn in the gall chamber. During winter it pupates. Very few individuals (3.5 \% of those examined in 1976) pupated without diapause and the adults emerged from galls from mid to late May, and other few ones $(3.8 \%$ in the same year) emerge from early October to early November without hibernation.

Differing from other native parasitoids, T. (S.) benejcus can complete its life cycle on the chestnut gall wasp, therefore, it had been thought to be an effective biological control agent. So, about 25 years ago, introduction and release tests of $T$. (S.) benejcus was attempted in forests where it had not

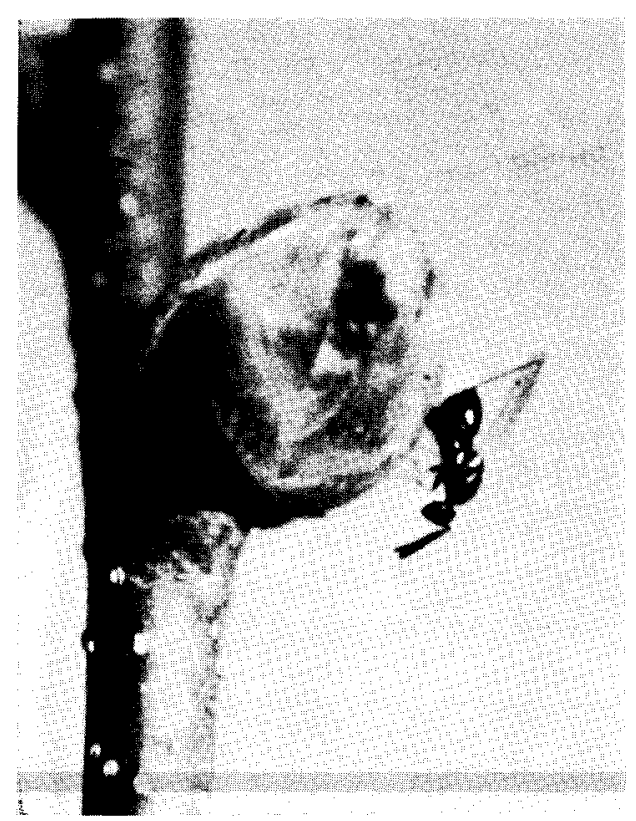

Fig. 1. An ovipositing female of Torymus (Syntomaspis) benejicus on a newly formed gall of Dryocosmus kuriphilus. 


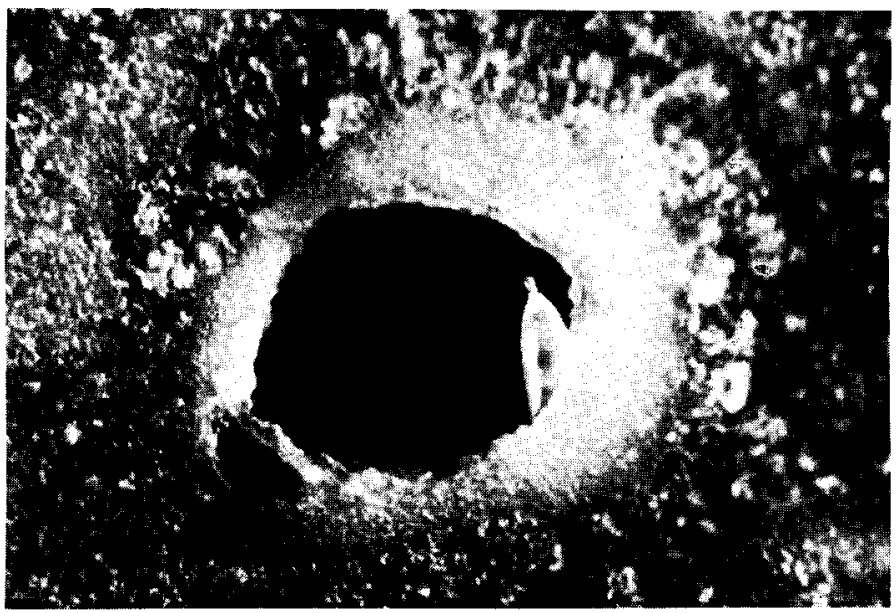

Fig. 2. A deposited egg of T. (S.) beneficus in a larval chamber of the D. kuriphilus gall attached to the chamber wall.

Table 2. Superparasitism in Torymus (Syntomaspis) beneficus. Newly formed galls were collected from a chestnut tree in Mt. Aburayama in April 1977 and afterwards dissected daily to examine the individual number and the developmental stage of parasitoids in each larval chamber.

\begin{tabular}{|c|c|c|c|c|c|c|c|c|c|c|}
\hline \multirow{3}{*}{$\begin{array}{l}\text { Date of } \\
\text { collection } \\
\text { of galls }\end{array}$} & \multirow{3}{*}{$\begin{array}{l}\text { Date of } \\
\text { dissection } \\
\text { of galls }\end{array}$} & \multirow{3}{*}{$\begin{array}{l}\text { No. of } \\
\text { galls } \\
\text { examined }\end{array}$} & \multirow{2}{*}{\multicolumn{2}{|c|}{$\begin{array}{r}\text { Frequency } \\
\text { parasitoi } \\
\text { larva }\end{array}$}} & \multicolumn{3}{|c|}{$\begin{array}{l}\text { distribution of } \\
\text { numbers per } \\
\text { chamber }\end{array}$} & \multicolumn{3}{|c|}{$\begin{array}{l}\text { Age distribution of } \\
\text { parasitoids examined }\end{array}$} \\
\hline & & & & & & & & \multirow[b]{2}{*}{ Egg } & \multirow{2}{*}{\multicolumn{2}{|c|}{$\begin{array}{l}\text { Young- Matur- } \\
\text { er ed } \\
\text { larva larva }\end{array}$}} \\
\hline & & & 0 & 1 & 2 & 3 & 4 & & & \\
\hline \multirow[t]{2}{*}{ April 17} & $\begin{array}{ll}\text { April } 18 \\
19\end{array}$ & $\begin{array}{l}12 \\
12\end{array}$ & 17 & 24 & $\begin{array}{r}12 \\
7\end{array}$ & 2 & 1 & $\begin{array}{c}40.4 \% \\
9.5\end{array}$ & $\begin{array}{l}59.6 \% \\
90.5\end{array}$ & $\begin{array}{l}0 \\
0\end{array}$ \\
\hline & 20 & 15 & 9 & 26 & 1 & 0 & 0 & 11.0 & 88.9 & 0 \\
\hline \multirow[t]{3}{*}{ April 24} & April 26 & 10 & 3 & 36 & 0 & 0 & 0 & 0 & 8.3 & 500 \\
\hline & 27 & 1010 & 106 & 32 & 0 & 0 & 0 & 0 & 16.1 & $83.991: 7$ \\
\hline & 28 & 10 & 5 & 19 & 0 & 0 & 0 & 0 & 0 ' & 100 \\
\hline
\end{tabular}

Table 3. Mortality of D. kuriphilus larvae through parasitization, host-feeding and sting for paralysis by females of $T$. (S.) benejicus. Galls were collected from a tree in Mt. Aburayama in the spring 1977 and dissected for examination.

\begin{tabular}{lccccc}
\hline $\begin{array}{c}\text { Date of } \\
\text { collection } \\
\text { of galls }\end{array}$ & $\begin{array}{c}\text { No. of } \\
\text { galls } \\
\text { examined }\end{array}$ & $\begin{array}{c}\text { No. of } \\
\text { host } \\
\text { larvae } \\
\text { examined }\end{array}$ & $\begin{array}{c}\text { No. of } \\
\text { hosts } \\
\text { parasitized }\end{array}$ & $\begin{array}{c}\text { No. of } \\
\text { hosts } \\
\text { killed by } \\
\text { host-feeding }\end{array}$ & $\begin{array}{c}\text { No. of } \\
\text { hosts } \\
\text { killed by } \\
\text { sting for } \\
\text { paralysis }\end{array}$ \\
\hline $\begin{array}{l}\text { April 24 } \\
\text { May 1 }\end{array}$ & 40 & 138 & 189 & 18 & 2 \\
\hline $\begin{array}{l}\text { Total } \\
\text { (Percentage) }\end{array}$ & 119 & 380 & 88 & 8 & 3 \\
\hline
\end{tabular}


yet occurred (Yasumatsu, 1958; Torii, 1959). Although this parasitoid induces high mortality through parasitization and host-feeding to larvae of the chestnut gall wasp as shown in Table 3 , the population of the gall wasp often continues at relatively high levels. Thus, the parasitoid has not been recognized as an effective natural enemy capable of regulating the pest population under an acceptable economic injury level.

\section{PARASITOIDS IN CHINA}

In China, the chestnut gall wasp was first recorded in 1958 by Tsou (1958), later than in Japan. But in Hopei Province past outbreak of the gall wasp was observed in 1941 and 1959960 (Murakami and Shimura, 1980; Murakami, 1980; Murakami et al., 1980). Therefore, I believe that its native home is China. From the view point of the biological control of the chestnut gall wasp, exploration for an efficient natural enemy in China should be particularly important because the gall wasp in China was presumably not a serious pest for a long time and some effective natural enemies might have been responsible for holding it at low densities.

In 1975 members of an investigation group of Japan Ministry of Agriculture and Forestry visited China and collected 69 galls of the chestnut gall wasp in a grove at a suburb of Hsi-an, Shensi Province and imported them to Japan. From these galls, 4 females and 3 males of Torymus (Syntomaspis) sp. emerged the following spring. Murakami et al. (1977) conducted a preliminary release test of the parasitoid. Only 3 females were liberated and they produced about 10 progeny per female on the average. Unfortunately, the progeny was all males. After final emergence of the parasitoids from the galls collected in Shensi, I opened them for examination and detected the dead adults or pupae of 5 other species of parasitoids (Murakami et al., 1977) as

Table 4. Parasitoid species of D. kuriphilus in China.

\begin{tabular}{lccc}
\hline \multirow{2}{*}{ Parasitoids } & \multicolumn{2}{c}{ China } & \\
& Shensi & Hopei & Japan \\
\cline { 2 - 3 } & & + & \\
Torymus (Syntomaspis) sp. & + & + & + \\
Megastigmus nipponicus & +1 & + & + \\
M. maculipennis & & + & + \\
Ermyrus punctiger & +1 & + & + \\
E. bruma setigera & +1 & + & + \\
Sycophila variegata & +1 & + & + \\
Eupelmus urozonus & + & + & + \\
Tetrastichus sp. & + & + & + \\
\hline
\end{tabular}

1) Megastigmus sp., Ormyrus sp. and Eudecatoma sp. recorded in Murakami et al. (1977) were determined as Megastigmus nipponicus, Omyns punctiger and Sycophila variegata, respectively. 2) The species identified as Eurytoma brunniventris in the same paper should be corrected to $E$. setigera. 
shown on the second column in Table 4.

Recently, I fortunately had an opportunity to visit Hopei Province, China in the summer 1979, and there I examined specimens preserved in the Hopei Fruit Tree Research Institute. I also collected galls in chestnut groves at Tsunhua, Hopei, and later I was given from a person several galls collected at Funing, Hopei. In all, approximately 2, 000 galls were imported into Japan. From the specimens in the Institute and imported galls, I recognized 9 species of parasitoids in Hopei Province (Murakami et al., 1980) as shown on the third column in Table 4.

Of the 10 species of Chinese parasitoids, 8 are common with Japanese native parasitoids, and 2 species have not been found from Japan. Of these 2 species occurring only in China, Tetrastichus sp. is probably a polyphagous and facultative hyperparasitoid, and Torymus (Syntomaspis) sp. is a dominant and presumably host-specific one. From the imported galls, 94 females and 71 males of Torymus (Syntomaspis) sp. have emerged in the spring 1980. They were released in cages for propagation in Fukuoka and Ibaragi Prefectures.

\section{COMPARISON OF CHARACTERS BETWEEN CHINESE AND JAPANESE TORYMUS (SYNTOMASPIS)}

The Chinese species of Torymus (Syntomaspis) is very closely related to the Japanese benejicus, but it can be distinguished by the length of the ovipositor. The Chinese species has a longer ovipositor than the Japanese one (Fig. 3). This makes it possible to attack the inner, deeper larval chamber of the host galls. The larvae in the inner chambers sometimes escape parasitization by

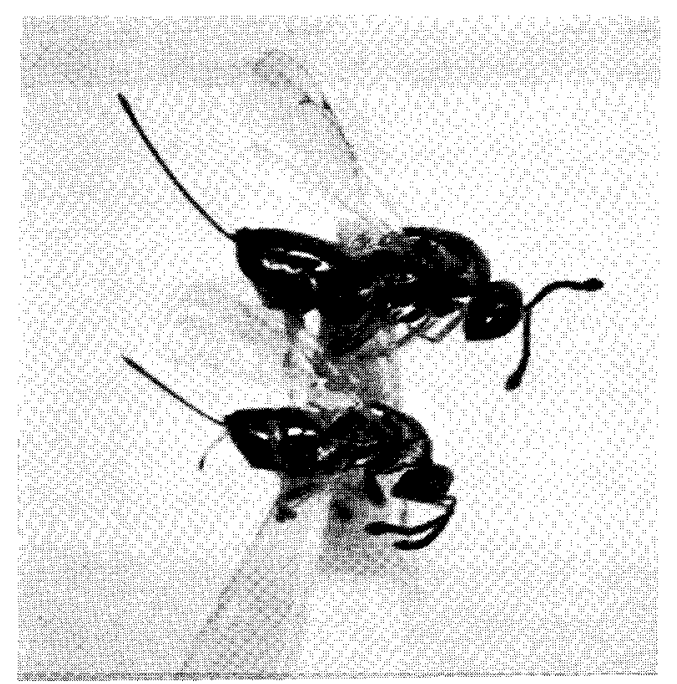

Fig. 3. Adult females of the Chinese Torymus (Syntomaspis) sp. (upper) and the Japanese $T$. (S.) beneficus (lower). 


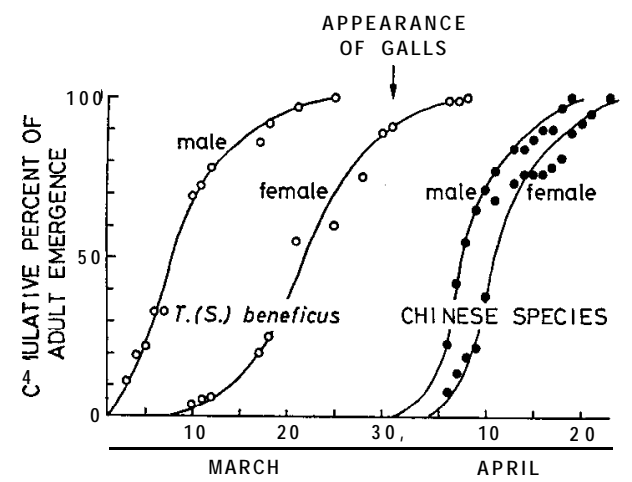

Fig. 4. The emergence period of the adults of the Chinese Tory m u s (Syntomaspis) sp. and the Japanese beneficus in Fukuoka, 1980.

Japanese benejcus owing to its shorter ovipositor (Tokuhisa, unpublished).

The emergence period of the adult of the Chinese species is more synchronous with the appearance of the host galls than is the Japanese benejcus as shown in Fig. 4. The first appearance of benejcus is about 3 weeks earlier than gall appearance, therefore, many individuals of benejcus emerged early may die without ovipositing in the host galls. While, the Chinese species emerge after the appearance of the galls, so all the females can attack the host galls.

Because of the longer ovipositor and better synchronized adult emergence, I expect the Chinese Torymus (Syntomaspis) sp. may be a more effective natural control agent than is the Japanese benejcus.

\section{ACKNOWLEDGEMENTS}

I wish to express my hearty thanks to Mr. Hsien-Bine Ao, Mr. Chang-Hui Chang and other members of staff of the Hopei Fruit Tree Research Institute who helped me in collecting galls and gave me the opportunity to examine specimens preserved in the Institute. Thanks are also due to Dr. Paul W. Schaefer, USDA for his kindness in reading through the manuscript and giving me several helpful suggestions. I also wish to thank Mr. Eiji Tokuhisa for fine photographs in this paper.

\section{REFERENCES}

Askew, R. R. 1975 The organisation of chalcid-dominated parasitoid communities centred upon endophytic hosts. In "Evolutionary Strategies of Parasitic Insects and Mites," ed. by P. W. Price, Plenum Press, New York and London, pp. 130-153

Murakami, Y. 1979 Validity of the "greenish gall" as an indicator for evaluating the effectiveness of parasitoids (Hymenoptera: Chalcidoidea) of Dryocosmus kuriphilus Yasumatsu (Hymenoptera : Cynipidae). J. Fuc. Agr., Kyushu Univ., 23 : 117-123

Murakami. Y. 1980 Current topics on the chestnut gall wasp, particularly reference to 
informations in China. Agr.\&Hort., 55: 249-253 (in Japanese)

Murakami, Y., Hsien-Bine Ao and Chang-Hui Chang 1980 Natural enemies of the chestnut gall wasp in Hopei Province, China (Hymenoptera: Chalcidoidea). Appl. Ent. Zool., $15: 184-186$

Murakami, Y. and I. Shimura 1980 The occurrence and present status of the chestnut gall wasp in China: An account of travels in chestnut groves in Hopei. Shokubutsu Boeki, 34: 17-20 (in Japanese)

Murakami, Y., K. Umeya and N. Oho 1977 A preliminary introduction and release of a parasitoid (Chalcidoidea, Torymidae) of the chestnut gall wasp, Dryocosmus kuriphilus Yasumatsu (Cynipidae) from China. Jap. J. appl. Ent. Zool., 21: 197-203 (in Japanese with English summary)

Shiraga. T. 1951 The chestnut gall wasp and its control. Agr. \&Hort., 26: 167-170 (in Japanese )

Tachikawa, T. 1973 Discovery of the hosts of Cynipencyrtus bicolor Ishii and Microterys tarumiensis Tachikawa (Hymenoptera : Chalcidoidea-Encyrtidae). Trans. Shikokw Ent.Soc., 11: $133-134$

Torii, T. 1959 Studies on the biological control of the chestnut gall wasp, Dryocosmus $k u$ riphilus Yasumatsu (Hymenoptera, Cynipidae), with particular reference to the utilization of its indigenous natural enemies. J.Fac.Agr.,Shinshu Univ., 2: 71-149

Tsou, Tsong-ling 1958 Pests of Fruit Trees in China, p. 312 (in Chinese)

Watanabe, C. 1957 A new species of Aspilota Förster parasitic on the chestnut gall wasp, Dryocosmus kuriphilus Yasumatsu (Hymenoptera, Braconidae). Mushi, 30: 35-36

Yasumatsu, K. 1955 Investigations on the parasites of the chestnut gallwasp. Shinrin Boeki News, 4: 100-102 (in Japanese)

Yasumatsu, K. 1958 Investigations on the distribution and release of natural enemies of the chestnut gallwasp. Report appl.Res. Min. Agr. Forest., Tokyo, 1958: 35-39 (in Japanese)

Yasumatsu, K. and K. Kamijo 1979 Chalcidoid parasites of Dryocosmus kuriphilus Yasumatsu (Cynipidae) in Japan, with descriptions of five new species (Hymenoptera). Esakia. 14: 93-111 